\title{
The Electrical Conductivity and Density of Pure Molten Thallium Sulphate and Equimolar Mixtures between Thallium Sulphate and Alkali Sulphates
}

\author{
Arnold Kvist and Kjell Schroeder \\ Department of Physics, Chalmers University of Technology, Göteborg, Sweden
}

(Z. Naturforsch. 23 a, 676-679 [1968] ; received 15 February 1968)

\begin{abstract}
The electrical conductivity and density of pure molten thallium sulphate and the conductivity of $\mathrm{TlMeSO}_{4}$, where $\mathrm{Me}=\mathrm{Li}, \mathrm{Na}, \mathrm{K}, \mathrm{Rb}$, or $\mathrm{Cs}$, have been measured between 700 and $1150^{\circ} \mathrm{C}$. We have also measured the densities of four equimolar sulphate mixtures and their pure components. The excess volumes were less than $0.5 \%$. The deviations from ideality for the conductivities and their Arrhenius activation energies have been compared with other sulphate systems. The electrical conductivity of a pure univalent sulphate depends both on the radius of the cation and on its mass. In mixtures, there are large negative excess conductivities and positive excess activation energies, when we have cations of different sizes.
\end{abstract}

In some recent papers ${ }^{1-5}$ we have reported on conductivity and also on some density measurements in different molten sulphate systems. Since we wanted to compare conductivities for mixtures, where the univalent cations have as different masses and radii as possible, we have now measured the electrical conductivity of $\mathrm{Tl}_{2} \mathrm{SO}_{4}, \mathrm{TlLiSO}_{4}, \mathrm{TlNaSO}_{4}$, $\mathrm{TlKSO}_{4}, \mathrm{TlRbSO}_{4}$ and $\mathrm{TlCsSO}_{4}$, and the densities of $\mathrm{Tl}_{2} \mathrm{SO}_{4}, \mathrm{Li}_{2} \mathrm{SO}_{4}$ and $\mathrm{TILiSO}_{4}$. For comparison, we have also measured the densities of some other sulphate mixtures and calculated the excess volumes.

\section{Experimental}

Conductivity measurements: The experimental technique is described elsewhere in detail ${ }^{4}$.

Density measurements: The method described previously ${ }^{4}$ was used with small modifications. The density bob was made of platinum and had a weight of about $20 \mathrm{~g}$.

All salts were of reagent quality, were well dried before use, and were used without further purification.

No decomposition of thallium sulphate was observed up to $1000{ }^{\circ} \mathrm{C}$, but at temperatures above about $750{ }^{\circ} \mathrm{C}$ the evaporation of salt was considerable at normal pressure. This is in agreement with observations made by Hegedüs and FukKer ${ }^{6}$.

\section{Results and Discussion}

The specific electrical conductivities and densities were generally determined from some degrees to

\footnotetext{
1 A. Kvist, Z. Naturforsch. 21 a, 487 [1966].

2 A. Kvist, Z. Naturforsch. 21 a, 1221 [1966].

3 A. Kvist, Z. Naturforsch. 21 a, 1601 [1966].

4 A. Kvist, Z. Naturforsch. 22 a, 208 [1967].
}

$100-200{ }^{\circ} \mathrm{C}$ above the melting points (Table 1 and 2). No conductivity data have previously been reported for these salts.

\begin{tabular}{|c|c|}
\hline$\stackrel{t}{{ }^{\circ} \mathrm{C}}$ & $\Omega^{-1} \stackrel{\varkappa}{\mathrm{cm}^{-1}}$ \\
\hline \multicolumn{2}{|c|}{$\mathrm{Tl}_{2} \mathrm{SO}_{4}$} \\
\hline 651.8 & 0.933 \\
\hline 665.0 & 0.957 \\
\hline 667.0 & 0.961 \\
\hline 680.6 & 0.989 \\
\hline 704.2 & 1.031 \\
\hline 720.8 & 1.066 \\
\hline 731.0 & 1.084 \\
\hline \multicolumn{2}{|c|}{$\mathrm{LiTlSO}_{4}$} \\
\hline 764.8 & 1.192 \\
\hline 781.8 & 1.239 \\
\hline 802.0 & 1.296 \\
\hline 816.0 & 1.335 \\
\hline 848.0 & 1.426 \\
\hline 866.2 & 1.474 \\
\hline 880.0 & 1.506 \\
\hline 897.5 & 1.550 \\
\hline 920.8 & 1.607 \\
\hline 922.0 & 1.615 \\
\hline \multicolumn{2}{|c|}{$\mathrm{NaTlSO}_{4}$} \\
\hline 787.6 & 1.236 \\
\hline 807.5 & 1.282 \\
\hline 827.5 & 1.319 \\
\hline 843.5 & 1.361 \\
\hline 862.5 & 1.399 \\
\hline 886.0 & 1.448 \\
\hline 902.2 & 1.479 \\
\hline 917.5 & 1.510 \\
\hline 937.2 & 1.551 \\
\hline
\end{tabular}

\begin{tabular}{cc}
\hline $\begin{array}{c}t \\
{ }^{\circ} \mathrm{C}\end{array}$ & $\begin{array}{c}\varkappa \\
\mathrm{cm}^{-1}\end{array}$ \\
\multicolumn{2}{c}{$\Omega^{\mathrm{KTISO}_{4}}$} \\
828.0 & 1.254 \\
851.8 & 1.306 \\
868.5 & 1.334 \\
892.2 & 1.377 \\
912.2 & 1.418 \\
931.8 & 1.456 \\
\multicolumn{2}{c}{ RbTlSO $_{4}$} \\
848.0 & 1.148 \\
880.2 & 1.215 \\
901.8 & 1.250 \\
917.2 & 1.275 \\
\multicolumn{2}{c}{$\mathrm{CsTlSO}_{4}$} \\
798.2 & 0.991 \\
824.5 & 1.036 \\
848.8 & 1.068 \\
864.2 & 1.095 \\
875.0 & 1.113 \\
902.0 & 1.163 \\
915.8 & 1.184 \\
933.2 & 1.209 \\
945.0 & 1.233 \\
\hline
\end{tabular}

Table 1. The specific electrical conductivities of the investigated salts.

5 A. Kvist, Z. Naturforsch. 22 a, 467 [1967].

6 A. J. Hegedüs and K. Fukrer, Z. Anorg. Allg. Chem. 284, 20 [1965]. 


\begin{tabular}{|c|c|c|c|}
\hline${ }^{t} \mathrm{C}$ & $\underset{\mathrm{g} / \mathrm{cm}^{3}}{\varrho}$ & $\stackrel{t}{{ }^{\circ} \mathrm{C}}$ & $\stackrel{\varrho}{\mathrm{g} / \mathrm{cm}^{3}}$ \\
\hline \multicolumn{2}{|c|}{$\mathrm{Li}_{2} \mathrm{SO}_{4}$} & \multicolumn{2}{|c|}{$\mathrm{LiNaSO}_{4}$} \\
\hline 915 & 1.982 & 737 & 2.096 \\
\hline 936 & 1.969 & 793 & 2.074 \\
\hline 959 & 1.963 & 853 & 2.046 \\
\hline 998 & 1.948 & 912 & 2.019 \\
\hline \multicolumn{2}{|c|}{$\mathrm{Na}_{2} \mathrm{SO}_{4}$} & 962 & 1.995 \\
\hline 903 & 2.062 & \multicolumn{2}{|c|}{$\mathrm{LiKSO}_{4}$} \\
\hline 942 & 2.043 & 789 & 2.009 \\
\hline 996 & 2.022 & 830 & 1.990 \\
\hline 1047 & 2.000 & 887 & 1.965 \\
\hline \multirow{2}{*}{\multicolumn{2}{|c|}{$\mathrm{K}_{2} \mathrm{SO}_{4}$}} & 939 & 1.944 \\
\hline & & 1009 & 1.913 \\
\hline $\begin{array}{l}1083 \\
1131\end{array}$ & $\begin{array}{l}1.809 \\
1.845\end{array}$ & 1064 & 1.889 \\
\hline 1151 & 1.832 & \multicolumn{2}{|c|}{$\mathrm{LiTlSO}_{4}$} \\
\hline \multirow{2}{*}{\multicolumn{2}{|c|}{$\mathrm{Tl}_{2} \mathrm{SO}_{4}$}} & 775 & 4.168 \\
\hline & & 801 & 4.145 \\
\hline $\begin{array}{l}080 \\
710\end{array}$ & $\begin{array}{l}5.503 \\
5.525\end{array}$ & 832 & 4.116 \\
\hline 726 & $\begin{array}{l}5.020 \\
5.500\end{array}$ & 878 & 4.073 \\
\hline 741 & $\begin{array}{l}5.500 \\
5.474\end{array}$ & 902 & 4.054 \\
\hline 757 & $\begin{array}{l}5.464 \\
5.455\end{array}$ & 925 & 4.029 \\
\hline 784 & $\begin{array}{l}5.450 \\
5417\end{array}$ & 967 & 3.989 \\
\hline 825 & $\begin{array}{l}5.416 \\
5.369\end{array}$ & 1006 & 3.952 \\
\hline 842 & 5.347 & \multicolumn{2}{|c|}{$\mathrm{NaKSO}_{4}$} \\
\hline 867 & 5.318 & 931 & 1.985 \\
\hline 888 & 5.289 & 959 & 1.971 \\
\hline 914 & 5.259 & 1018 & 1.945 \\
\hline 943 & 5.219 & 1087 & 1.916 \\
\hline
\end{tabular}

Table 2. The densities of the investigated salts.

The density results can be described by simple linear relations (Table 3 ) with a standard deviation of less than $0.1 \%$. A comparison between our results

\begin{tabular}{|c|c|c|c|c|c|c|}
\hline Salt & $\underset{\mathrm{g} / \mathrm{cm}^{3}}{a}$ & $\begin{array}{l}-b \cdot 10^{-3} \\
\mathrm{~g} / \mathrm{cm}^{3},{ }^{\circ} \mathrm{C}\end{array}$ & $\begin{array}{c}s \\
\mathrm{~g} / \mathrm{cm}^{3}\end{array}$ & $\begin{array}{c}\text { Interval } \\
{ }^{\circ} \mathrm{C}\end{array}$ & $\begin{array}{c}\varrho\left(1000^{\circ} \mathrm{C}\right) \\
\mathrm{g} / \mathrm{cm}^{3}\end{array}$ & نَ \\
\hline \multirow[t]{3}{*}{$\mathrm{Li}_{2} \mathrm{SO}_{4}$} & 2 & & 0 . & 91 & & \\
\hline & & & 0.0 & 0 & & 4 \\
\hline & & & - & 0 & & \\
\hline \multirow[t]{2}{*}{$\mathrm{Na}_{2} \mathrm{SO}_{4}$} & & & 0.001 & 7 & 2. & \\
\hline & 2.4 & & - & 6 & 2 . & $\begin{array}{llll}7 & & \end{array}$ \\
\hline \multirow[t]{2}{*}{$\mathrm{K}_{2} \mathrm{SO}_{4}$} & 2.4 & 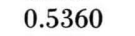 & 0.001 & $1083-1151$ & 1.9 & \\
\hline & 2 & & - & 110 & 1.9 & \\
\hline & 6. & & .0 & $680-943$ & 5.1 & \\
\hline & 2.430 & 0.45 & 0.002 & $737-962$ & 1.976 & \\
\hline $\mathrm{LiKSO}_{4}$ & 2.351 & 0.4337 & 0.001 & $789-1064$ & 1.817 & \\
\hline & 4.894 & 0.9355 & 0.002 & $775-1006$ & 3.958 & \\
\hline NaKSC & 2.394 & 0.4399 & 0.001 & $931-1087$ & 1.954 & \\
\hline
\end{tabular}

Table 3. The densities described by the relation $\varrho=a+b t$, where $t$ is the temperature in ${ }^{\circ} \mathrm{C}$, compared with previous results. $s$ is the standard deviation.

7 F. Jaeger and J. Kahn, Koninkl. Ned. Akad. Wetenschap. Proc. 19, 381 [1916].

8 A. R. Ubbelohde, Nature 206, 246 [1965].

9 A. Kvist and A. LundÉn, Z. Naturforsch. 20 a, 235 [1965].

10 I. S. YAffe and E. R. van Artsdalen, J. Phys. Chem. 60, 1125 [1956]. and previous ones shows good agreement for $\mathrm{Li}_{2} \mathrm{SO}_{4}$ (l. c. ${ }^{4,7}$ ) and $\mathrm{Na}_{2} \mathrm{SO}_{4}$ (l. c. ${ }^{7}$ ), but not for $\mathrm{K}_{2} \mathrm{SO}_{4}$, where our results are more than $3 \%$ higher than those obtained by JAEGER and $\mathrm{KAHN}^{7}$.

According to UBBELOHDE ${ }^{8}$ most molten salt systems show a change from a negative excess volume at low melting temperatures to relative large positive deviations at higher temperatures. In the investigated sulphate mixtures (Table 4 ) and also in $\mathrm{LiAgSO}_{4}$ (l. c. ${ }^{4}$ ) the excess volumes at $1000{ }^{\circ} \mathrm{C}$, which are positive, are less than $0.5 \%$. These systems can thus be considered ideal.

\begin{tabular}{lccc}
\hline Salt & $\begin{array}{c}V \text { (measured) } \\
\text { cm }\end{array}$ & $\begin{array}{c}V \text { (ideal) } \\
\mathrm{cm}^{3} / \text { mole }\end{array}$ & $\begin{array}{c}\text { Difference } \\
(\%)\end{array}$ \\
\hline $\mathrm{LiNaSO}_{4}$ & 63.68 & 63.40 & 0.4 \\
$\mathrm{LiKSO}_{4}$ & 74.13 & 73.76 & 0.5 \\
$\mathrm{LiTISO}_{4}$ & 77.65 & 77.30 & 0.4 \\
$\mathrm{NaKSO}_{4}$ & 80.95 & 80.69 & 0.3 \\
\hline
\end{tabular}

Table 4. The measured molar volumes compared with the ideal molar volumes at $1000{ }^{\circ} \mathrm{C}$.

For the calculation of the molar electrical conductivities $(\Lambda)$ of $\mathrm{TIRbSO}_{4}$ and $\mathrm{TlCsSO}_{4}$, we have used density data for $\mathrm{Rb}_{2} \mathrm{SO}_{4}$ and $\mathrm{Cs}_{2} \mathrm{SO}_{4}$ obtained by $\mathrm{J}_{\mathrm{AEGER}}$ and $\mathrm{K}_{\mathrm{AHN}}{ }^{7}$ and assumed that the excess volume is negligible.

The temperature dependence of $A$ can be expressed in several different ways ${ }^{9}$. In all molten sulphates we have studied so far, we have found that the results with satisfactory precision can be written as $A=a+b t$. The standard deviation of $A$ is then about $0.2 \%$ and no definite curvatures have been observed. $A$ has often been described by the relation $\Lambda=a+b t+c t^{2}$, which leads to a conductivity maximum. For $\mathrm{LiI}$ (l.c. ${ }^{10}$ ) and $\mathrm{Li}_{2} \mathrm{WO}_{4}$ (l.c. ${ }^{11}$ ) this should occur at comparably low temperatures, but in more careful measurements no low temperature maxima could be detected ${ }^{12,13}$. Also discontinous conductivity changes have been reported ${ }^{\mathbf{1 4}}$.

Deviations from linearity might probably with few exceptions ${ }^{15}$ be explained by decomposition of the salt.

11 K. B. Morris and P. L. Robinson, J. Chem. Eng. Data 9, 444 [1964].

12 W. Karl and A. Klemm, Z. Naturforsch. 19 a, 1619 [1964].

13 A. Kvist, unpublished.

14 S. Brillant, C. R. Acad. Sci. Paris 262, 447 [1966].

15 L. F. Grantham and E. R. van Artsdalen, J. Phys. Chem. 67, 2506 [1963]. 
Linear equations for $\Lambda$ are given in Table 5 .

\begin{tabular}{lcccc}
\hline Salt & $\begin{array}{c}-a \\
\Omega^{-1} \mathrm{~cm}^{2}\end{array}$ & $\begin{array}{c}b \\
\Omega^{-1} \mathrm{~cm}^{2}{ }^{\circ} \mathrm{C}^{-1}\end{array}$ & $\begin{array}{c}s \\
\Omega^{-1} \mathrm{~cm}^{2}\end{array}$ & $\begin{array}{c}\text { Interval } \\
{ }^{\circ} \mathrm{C}\end{array}$ \\
\hline $\mathrm{Tl}_{2} \mathrm{SO}_{4}$ & 43.8 & 0.19620 & 0.1 & $651-731$ \\
$\mathrm{LiTlSO}_{4}$ & 84.5 & 0.22534 & 0.2 & $764-922$ \\
$\mathrm{NaTlSO}_{4}$ & 55.9 & 0.19699 & 0.2 & $787-937$ \\
$\mathrm{KTlSO}_{4}$ & 59.4 & 0.20883 & 0.2 & $828-931$ \\
RbTlSO $_{4}$ & 65.8 & 0.20881 & 0.2 & $848-917$ \\
CsTlSO $_{4}$ & 55.0 & 0.19720 & 0.4 & $798-945$ \\
\hline
\end{tabular}

Table 5. The temperature dependence of the molar electrical conductivities described by the equation $A=a+b t$, where

$t$ is the temperature in ${ }^{\circ} \mathrm{C}$. $s$ is the standard deviation.

We have calculated two parameters for our further discussions; the molar electrical conductivity at $900{ }^{\circ} \mathrm{C}$ (Table 6) and the Arrhenius activation energy $Q$ (Table 7) obtained from the relation

$$
\Lambda=\Lambda_{0} \exp (-Q / R T) \text {. }
$$

\begin{tabular}{lrrrrrrr}
\hline Salt & $\mathrm{Li}_{2} \mathrm{SO}_{4}$ & $\mathrm{Na}_{2} \mathrm{SO}_{4}$ & $\mathrm{~K}_{2} \mathrm{SO}_{4}$ & $\mathrm{Rb}_{2} \mathrm{SO}_{4}$ & $\mathrm{Cs}_{2} \mathrm{SO}_{4}$ & $\mathrm{Tl}_{2} \mathrm{SO}_{4}$ & $\mathrm{Ag}_{2} \mathrm{SO}_{4}$ \\
\hline $\mathrm{Li}_{2} \mathrm{SO}_{4}$ & 242.5 & 174.0 & 122.6 & 95.6 & 84.0 & 118.3 & 172.0 \\
$\mathrm{Na}_{2} \mathrm{SO}_{4}$ & 174.0 & 159.3 & 128.4 & 105.4 & 96.3 & 121.4 & - \\
$\mathrm{K}_{2} \mathrm{SO}_{4}$ & 122.6 & 128.4 & 134.6 & 121.6 & 113.4 & 128.6 & - \\
$\mathrm{Rb}_{2} \mathrm{SO}_{4}$ & 95.6 & 105.4 & 121.6 & 112.8 & 105.6 & 122.1 & - \\
$\mathrm{Cs}_{2} \mathrm{SO}_{4}$ & 84.0 & 96.3 & 113.4 & 105.6 & 111.3 & 122.4 & - \\
$\mathrm{Tl}_{2} \mathrm{SO}_{4}$ & 118.3 & 121.4 & 128.6 & 122.1 & 122.4 & 132.8 & - \\
$\mathrm{Ag}_{2} \mathrm{SO}_{4}$ & 172.0 & - & - & - & - & - & 156.5 \\
\hline
\end{tabular}

Table 6. The molar electrical conductivities in $\Omega^{-1} \mathrm{~cm}^{2}$ of pure molten sulphates and equimolar sulphate mixtures at $900^{\circ} \mathrm{C}$.

\begin{tabular}{lccccccc}
\hline Salt & $\mathrm{Li}_{2} \mathrm{SO}_{4}$ & $\mathrm{Na}_{2} \mathrm{SO}_{4}$ & $\mathrm{~K}_{2} \mathrm{SO}_{4}$ & $\mathrm{Rb}_{2} \mathrm{SO}_{4}$ & $\mathrm{Cs}_{2} \mathrm{SO}_{4}$ & $\mathrm{Tl}_{2} \mathrm{SO}_{4}$ & $\mathrm{Ag}_{2} \mathrm{SO}_{4}$ \\
\hline $\mathrm{Li}_{2} \mathrm{SO}_{4}$ & 2590 & 5170 & 6420 & 6340 & 6370 & 5310 & 4590 \\
$\mathrm{Na}_{2} \mathrm{SO}_{4}$ & 5170 & 4460 & 5680 & 4910 & 6190 & 4720 & - \\
$\mathrm{K}_{2} \mathrm{SO}_{4}$ & 6420 & 5860 & 4910 & 4850 & 4970 & 4430 & - \\
$\mathrm{Rb}_{2} \mathrm{SO}_{4}$ & 6340 & 4910 & 4850 & 4970 & 4630 & 4690 & - \\
$\mathrm{Cs}_{2} \mathrm{SO}_{4}$ & 6370 & 6190 & 4970 & 4630 & 4530 & 4380 & - \\
$\mathrm{Tl}_{2} \mathrm{SO}_{4}$ & 5310 & 4720 & 4430 & 4690 & 4380 & 3940 & - \\
$\mathrm{Ag}_{2} \mathrm{SO}_{4}$ & 4590 & - & - & - & - & - & 3180 \\
\hline
\end{tabular}

Table 7. The Arrhenius activation energies in cal $/ \mathrm{mole}$ for pure molten sulphates and equimolar sulphate mixtures.

The physical meaning of $Q$ is perhaps doubtful, but $Q$ has been discussed in the literature for various systems.

As we have found previously ${ }^{5}$, the conductivities of the pure alkali sulphates increase when the radii of the cations decrease. The Pauling radii of the thallium and rubidium ions are almost equal, but the conductivity of $\mathrm{Tl}_{2} \mathrm{SO}_{4}$ is considerably higher than of $\mathrm{Rb}_{2} \mathrm{SO}_{4}$. Also for $\mathrm{Ag}_{2} \mathrm{SO}_{4}$ the conductivity is comparably higher than for the alkali sulphates. This mass dependence of the conductivity has the

16 A. Kvist, Thesis, Göteborg 1967. opposite direction compared with the isotopic enriched salts ${ }^{6} \mathrm{Li}_{2} \mathrm{SO}_{4}$ and ${ }^{7} \mathrm{Li}_{2} \mathrm{SO}_{4}$, were the conductivity is $4.2 \%$ higher in ${ }^{6} \mathrm{Li}_{2} \mathrm{SO}_{4}$ than in ${ }^{7} \mathrm{Li}_{2} \mathrm{SO}_{4}$, and which has been explained by the mass difference ${ }^{1,16}$. However, the molar volume of $\mathrm{Tl}_{2} \mathrm{SO}_{4}$ is greater than of $\mathrm{Rb}_{2} \mathrm{SO}_{4}$ and this means that also the free volume is greater, which might explain the difference.

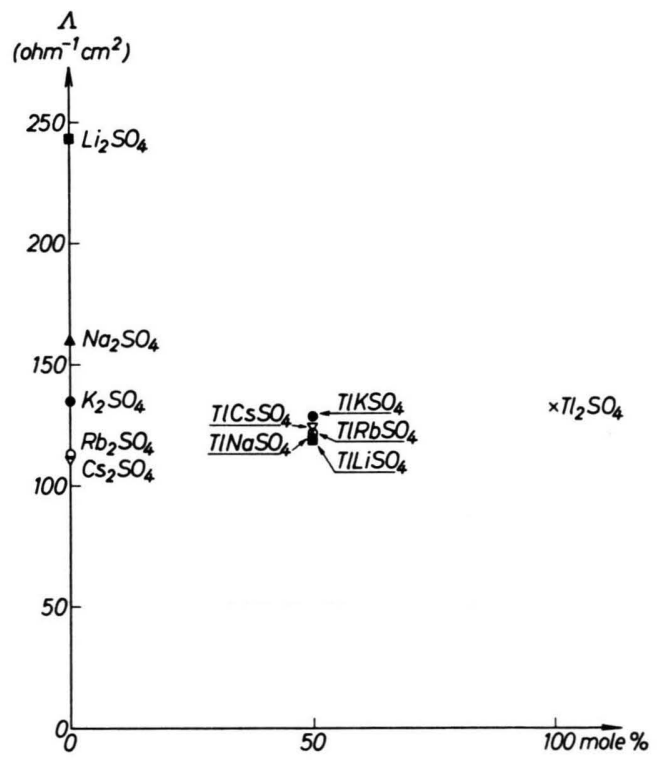

Fig. 1. The equivalent electrical conductivity of $\mathrm{Tl}_{2} \mathrm{SO}_{4}$, $\mathrm{Me}_{2} \mathrm{SO}_{4}$ and $\mathrm{TlMeSO}_{4}$.

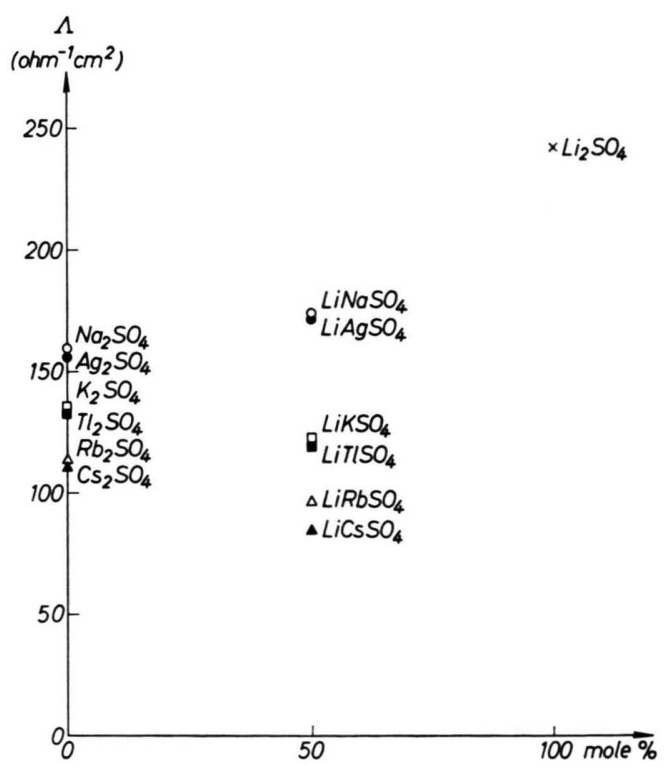

Fig. 2. The equivalent electrical conductivity of $\mathrm{Li}_{2} \mathrm{SO}_{4}$, $\mathrm{Me}_{2} \mathrm{SO}_{4}$ and $\mathrm{LiMeSO}_{4}$. 
In the equimolar mixtures, the conductivity mainly depends on the heavier cation. This can be explained by assuming some sort of cooperative motions in the salt ${ }^{5}$, where a light cation, for instance a lithium ion in thallium sulphate, moves with the same velocity as the thallium ions. A result of this is that the conductivity of $\mathrm{TlMeSO}_{4}$ almost is the same for all Me (Fig. 1). For $\mathrm{LiMeSO}_{4}$ the situation is reversed (Fig. 2). It can also be observed that in the mixture $\mathrm{Tl}_{2} \mathrm{SO}_{4}-\mathrm{Rb}_{2} \mathrm{SO}_{4}$ and in other mixtures, where the cation radii are narly equal, both $\Lambda$ and
$Q$ are ideal. This has been observed also for nitrates ${ }^{17}$. A comparison between Table 6 and 7 shows that when we mix two salts with very different cation radii, we obtain a very large positive excess activation energy and a negative excess conductivity. This is in agreement with the model mentioned above, since the free volume of a sulphate increases with the radius of the cation ${ }^{5}$.

This work was supported financially by Magnus Bergvalls Stiftelse.

17 V. Wagner and S. Forcheri, Z. Naturforsch. 22 a, 891 [1967].

\title{
Diffusion in Cubic Sulphates
}

\author{
I. Univalent Cations in Pure Lithium Sulphate \\ Arnold Kvist and Ante Bengtzelius \\ Department of Physics, Chalmers University of Technology, Göteborg \\ (Z. Naturforsch. 23 a, 679-682 [1968] ; received 29 February 1968)
}

\begin{abstract}
The interdiffusion coefficients $(D)$ of $\mathrm{Na}^{+}, \mathrm{Ag}^{+}, \mathrm{K}^{+}, \mathrm{Rb}^{+}$and $\mathrm{Tl}^{+}$in pure f.c. c. $\mathrm{Li}_{2} \mathrm{SO}_{4}$ have been measured between 590 and $820^{\circ} \mathrm{C}$. $D$ and the Arrhenius' activation energies decrease in the same order as the ionic radii increase. $D$ is a function both of the masses and the radii of the impurity cations. The results show that the $\mathrm{Na}^{+}$and $\mathrm{Ag}^{+}$ions mainly diffuse in the sulphate lattice with the same mechanism as the lithium ions, while the larger ions are mobile in defects in the lattice. The $\mathrm{Li}^{+}, \mathrm{Na}^{+}$and $\mathrm{Ag}^{+}$ions are probably diffusing between octahedral positions.
\end{abstract}

Some salts form cubic high temperature modifications with extremely high mobility of the cations. Such modifications can be found in e. g. AgI (l.c. $\left.{ }^{1-2}\right), \mathrm{Li}_{2} \mathrm{SO}_{4}$ (l. c. ${ }^{3-5}$ ), $\mathrm{LiAgSO}_{4}$ (l. c. ${ }^{6-7}$ ) and $\mathrm{LiNaSO}_{4}$ (l. c. $\left.{ }^{7-8}\right)$. During the last years we have made a great number of investigations of especially lithium sulphate and we have now started a serie of measurements of different diffusion coefficients in cubic sulphates. We report here on measurements of the interdiffusion coefficients of the univalent cations $\mathrm{Na}^{+}, \mathrm{Ag}^{+}, \mathrm{K}^{+}, \mathrm{Tl}^{+}$and $\mathrm{Rb}^{+}$in f. c. c. $\mathrm{Li}_{2} \mathrm{SO}_{4}$. The self-diffusion coefficient of lithium in this modification has recently been published ${ }^{4}$ and measurements of thermal diffusion coefficients have also been reported ${ }^{8-9}$.

1 A. Kvist and A.-M. Josefron, Z. Naturforsch. 23 a, 625 [1968].

2 G. Burley, American Mineralogist 48, 1266 [1963].

3 A. Kvist, Z. Naturforsch. 21 a, 487 [1966].

4 A. Kvist and U. Trolle, Z. Naturforsch. 22 a, 213 [1967].

5 A. Kvist, Thesis, Göteborg 1967.

\section{Experimental}

All salts were of reagent quality and were used without further purification. The diffusion cells were made of pure quartz (Fig. 1) and all measurements were performed in air. Pure lithium sulphate was molten in the bottom of the tube, which was placed in a big furnace. When the salt had solidified to an about $70 \mathrm{~mm}$ long column and the experimental temperature was reached, we inserted a funnel, which contained a few small lumps of lithium sulphate with $2-3$ mole\% of the impurity cation. The salt in the funnel was molten by means of a small winding around the tube and in this way an about $0.5 \mathrm{~mm}$ thick layer of salt containing impurities was obtained on the surface of the salt column. The cell was then held at constant temperature for $3-8$ hours, when it was rapidly cooled to room temperature. Samples were taken at every fourth $\mathrm{mm}$ of the salt column, and were analysed by means of flame spectrophotometry.

6 A. Kvist, Z. Naturforsch. 22 a, 208 [1967].

7 H. ØуЕ, Thesis, Trondheim 1963.

8 A. Kvist, Z. Naturforsch. 22 a, 467 [1967].

9 A. LundÉn and J.-E. Olsson, Z. Naturforsch., in press. 